\title{
Educational Organizational and Leadership Analysis in Elementary School
}

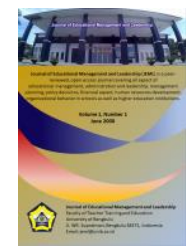

\section{Badrud Tamam ${ }^{1}$, Cucun Sunaengsih ${ }^{2}$, Noneng Safitri ${ }^{2}$, Rima Nurul Hotimah $^{2}$, Wakhidah Mumtazah ${ }^{2}$, Gita Rahmadhani ${ }^{2}$}

\author{
${ }^{1}$ Study Program of Education Management, Postgraduate School \\ Wiralodra University, Indramayu, Indonesia \\ Email: badrud83@gmail.com \\ ${ }^{2}$ Undergraduate Study Program of Elementary School Teacher Education \\ Universitas Pendidikan Indonesia, Bandung, Indonesia \\ Email: cucunsunaengsih@upi.edu
}

DOI: https://doi.org/10.33369/jeml.1.1.25-30

\begin{abstract}
The aim of this research was to determine educational organization and leadership in elementary school in West Java, Indonesia by principals as the research informants. The method used was qualitative research method with analysis descriptive approach. This research qualitatively describes and analyzes principal leadership style and educational organization in improving teacher performance in elementary schools in West Java, Indonesia. The data collection technique was using interview and documentation study techniques. Results of the research show that 1 . There is not too complex organizational structure seen from organizational horizontal differential aspect as well as the organizational structure is not standard; 2. Principal leadership greatly influences on teacher performance. From the findings, it is necessary for a visionary leader with ability to support the organization to be more dynamic one and influence positively on improvement of teacher performance.
\end{abstract}

Keywords: Leadership, educational organization, school principal.

\section{INTRODUCTION}

Organization is a place to gather a group of people in order to cooperate in a rational, structured, controlled and guided manner in order to achieve specific goals which have been determined by utilizing available resources (Korumaz, 2017). Requirement of human currently in an organization aims to achieve common goals in a more effective and efficient manner. Education world as an investment in developing human resources is an effort carried out in the context of organization, in which in this current modern era, parents with all of their business give more trust at education process for their children to formal educational organization in the form of school. Thus, education process in an organization shows existence of educational organization is addressed to achieve educational goals in a more effective and efficient manner (Science et al., 2018).

In running an effective organization, it is necessary for a leader having high level of leadership spirit, which enables a process of influencing or giving examples and motivating which is carried out by a leader to his members in the effort of achieving organizational goals (Gochhayat, Giri, \& Suar, 2016). Leadership serves as a very important factor in an educational organization. Leadership is an inseparable aspect of 
organizational since leadership of an organizational leader has considerable effects on the organizational (Tsai, 2011). Understanding and identifying various aspects of organization are one of the basic competence which must be owned by a leader (Yahchouchi, 2009). A leader does not only have main tasks in regulating or leading, but he also has functions as an educational manager with positive attitude so that he can support his members and groups to cooperate in a group, in order to achieve organizational goals (Tsai, 2011).

In achieving the goals of educational organizations, it is greatly necessary for leadership skills and wisdom by school principals as educational leaders (Bush, 2007). In order to realize a success by the principal in achieving organizational goals, the principal must have a very important role in coordinating, mobilizing, and adjusting available educational resources (Raman, Mey, Don, Daud, \& Khalid, 2015). Principal's leadership plays an important role in encouraging schools to realize their vision, mission, goals and targets through school programs that will be implemented in a planned and gradual manner (Keskes, 2013).

There will be successful principal's tasks if the principal understands the task to be carried out (S.Uko, 2015). Therefore, the principal must be able to direct, guide, influence thoughts, and feelings or behavior of the teacher or other people. School leadership style is a process in which there are elements that can influence on how principals lead (Ibrahim \& Al-Taneiji, 2013). The leadership style will be implemented if the principal in leading is accompanied by cooperation and the existence of a vision and mission to achieve common goals. In the leadership, principals will always influence on teacher performance as well as in terms of creating an atmosphere of a conducive school environment (Yahchouchi, 2009). Then, there are often arising problems when there is a gap between the demands of the organization as well as task realization carried out its members (Baumgartner, 2009). There are often also complex problems in a school organization and ultimately this will require a principal to make right decisions. This makes researchers interested in describing how educational organizations and educational leadership are implemented. By the description on this educational organization and educational leadership, it will analyze how the organization and leadership of education influence on teacher performance and influence on achieving organizational goals.

\section{RESEARCH METHOD}

This research used a qualitative method with a descriptive analytical approach. This qualitative procedure was expected to be able to produce descriptive data in the form of verbal or written words from people and the behavior of the events experienced (Bogdan and Taylor, 1975). Meanwhile, according to Kirk and Miller, this qualitative research will help the researchers in understanding phenomena about what is experienced by research subjects such as behavior, perception, motivation, action, and others holistically in a special natural context and by utilizing various natural methods. The main subject of this research is school organization and principal leadership style in improving the quality of teacher performance in West Java, Indonesia. Information in this research is the school principal in West Java, Indonesia. The data collection technique was by interview with the principals, and including documents from the works of teachers and observations during the research activities.

\section{RESULTS AND DISCUSSION}

From the results of the research, it can obtain information showing that school organizational structure was formed based on the results of a joint discussion between the principal, teachers, and related staff. In addition, there is not too complex level of organizational complexity seeing from horizontal differentiation since there is not too 
much work to be done by employees in the organization or school. A concrete example of horizontal differentiation is functional specialization implemented by schools that divide the tasks or work of the school to each of its employees. Principals also conducts formalization by standardizing work within educational organizations to reduce diversity. Schools also adhere to a decentralized system which means that there are many appropriate issues of the education office to decide, but the school still has a prerogative right for several things.

Organizational structure at school has a nature of not standardized one which it can be changed each year. Teachers do not only have a task as a teacher, but they also have additional tasks presented in Minimum Learning Completeness Standard (SKBM). In the SKBM, there are three main tasks of teachers, namely teaching and learning, extracurricular and division of financial task, in addition to other tasks namely assisting principals in regulating content standard, process standard, passing standard and educational standard, treasury and library. If the principal is absence, then he will delegate his tasks to the trusted teacher.

Educational organization in elementary school has weakness in the aspect of educators, in which there are schools having limited number of educators. So, it is greatly necessary for the school to have skilled educators and have ability to run their tasks. By lack of educators, the school then face a number of problems, among others obstacles in learning process in the class in which when the teachers are absence, though in a certain time, they are replaced by other teachers, but the learning process is yet less optimal, so it is greatly necessary for additional educators. Existing educational organizational structure at school is not standard, so if there is one of the elements which is inappropriate or has no good functions, then the educational organizational structure can be changed and adjusted. The form of organizational can be highlighted since in a decision-making process, there is always a discussion between all members of school organization. Due to the form of organization, all of educational organization members at school must eliminate their ego and must prioritize the interest of the group.

Related to educational leadership in schools, the type of leadership used by school principals is a democratic type. This style is carried out by always inviting subordinates to negotiate any problems faced by schools. The principal shows that it can prevent any authoritarian leadership by holding frequent discussion, which will then result in a mutually-agreed decision. In the school world, there are no absolute or absolute decisions, at least the principal carries out a meeting once a month even though it is not an official meeting or discussion. Responsible leaders will not let their members make mistakes continuously because in every organization there must be a leader with willingness to prevent its members from behaving arbitrarily. In facing problems conducted by school staff, principals as leaders still cannot act fully on the staff, because there are still related offices giving sanctions.

In running the tasks, a leader does not only have to use specific style, he must also be sensitive to any situation by the employees in order to understand and identify any necessity for each member (Bakhshi, Kumar, \& Rani, 2009). In a leadership, a leader must be fair though in an organization, a leader may have any specific trusted person but this may not lead to unfair leader since this can be a fatal issue in an organization. Leaders must understand their tasks as a leader which must have good communication skills in order to create good organizational operation (Örgütsel \& Rolü, 2018).

When there is one of the organizational members violating rules, then the principal as a leader may carry out guidance. However, if any guidance taken still leads to such violating act, then the principal is permitted to report to the Technical Implementation Unit in order to act toward the member. To be a good leader, each prospective principal will go 
through training in advance, the training includes a series of tests, skill and leadership training, finally there will be given certificate as an evidence that the prospective principal has joined the training. A good leader is a leader giving attention to his partners, going through a special training, and having sensitivity to his members. In his actions, a leader must have ability to maintain his emotion, adjust to any situations and conditions, as well as must be professional in running his tasks. A good leader is a wise leader having vision and mission, a smart and loyal one as well as one having high dedication.

Based on the research results, we carried out an analysis using SWOT metrics. This analysis helps the researchers to analyze descriptive situations and conditions (give an idea). The analysis places situations and conditions as input factors, which are then grouped according to their respective contributions. One thing that needs to be remembered and noted by users, that this analysis is solely as a form of analysis that is magical and able to provide solution for a problem. In addition, using a strength framework, opportunity/ chances, weaknesses and threats, this analysis can provide a simple form / way to prove the best way to implement a strategy. In addition, this analysis can help planners to know what can be achieved, and what things can be noticed by the planners.

Strength which can be obtained from the research results are democratic leadership style, harmonious relationship between principals and employees as organizational members, complexity of functional system in division of task or school works for each employee, decision making conducted by principal as organizational leader, and consideration to opinions given by organizational members. There are also opportunities namely orientation for new educators and educational personnel in the form of special guidance in order to create more professional educators, so that having ability to face employees.

Weaknesses that can be obtained from the research results are limited members in the organizational system leading to task accumulation in several members, and necessity to grow a sense of belonging and a sense of kinship so that each member can carry out their duties properly and not arbitrary.

Opportunities that can be obtained from the research results are that the principals can take advantage of the capabilities owned by organizational members in order to achieve organizational goals. Through the existence of a good leadership style from the principal, a conducive school climate and achievement motivation from the bottom of the teacher's heart, teachers will be fulfilled his hopes, authority, and awareness in improving performance.

Threats that can be obtained from the research results are lack of educators who can threaten school organizational system and influence on certain tasks due to lack of human resources. There is not supportive school climate, for example formation of groups that will disrupt the work system.

From the above analysis, it can be clearly seen that educational organization and leadership at school are two inseparable issues. Both cooperate and collaborate in order to find solutions for any facing problems at school. Likewise, the strategies used in achieving school goals require solid collaboration between educational organizations and leadership in schools. Thus, it cannot only improve the teacher performance, but it will also improve the quality of education entirely.

\section{CONCLUSIONS}

Based on the results of research on discussions concerning "Organization and Educational Leadership in Elementary Schools in West Java, Indonesia", it can be concluded that the system applied to an educational organization influences on how the 
organization achieves it goals or vision and mission. The type of leadership used by principals also influences on how to run the organization of education at schools. There is not necessarily an existence of good principal, but it requires special training. The adequate number of organization members and one with ability to handle each task properly are a form of supports in the formation of a good organization in order to achieve organizational goals.

\section{REFERENCES}

Bakhshi, A., Kumar, K., \& Rani, E. (2009). Organizational justice perceptions as predictor of job satisfaction and organization commitment. International Journal of Business and Management, 4, 145-154.

Baumgartner, R. J. (2009). Organizational Culture and Leadership: A Sustainable Corporation. Sustainable Development, 113(3), 102-113.

Bush, T. (2007). Educational leadership and management: theory, policy, and practice. South African Journal of Education, 27, 391-406. Retrieved from http://www.sajournalofeducation.co.za/index.php/saje/article/view/107/29

Bogdan, R. and Taylor, S.J. 1975. Introduction to Qualitative Research Methode. New York: John Willey and Sons, 1975

Gochhayat, J., Giri, V. N., \& Suar, D. (2016). Multilevel leadership and organizational effectiveness in Indian technical education: the mediating role of communication, power and culture. International Journal of Leadership In Education, 3124, 1-15.

Ibrahim, A. S., \& Al-Taneiji, S. (2013). Principal leadership style, school performance, and principal effectiveness in Dubai schools. International Journal of Research Studies in Education, 2(1), 41-54.

Keskes, I. (2013). Relationship between leadership styles and dimensions of employee organizational commitment: A critical review and discussion of future directions. Intangible Capital, 10(1), 26-51. https://doi.org/org/10.3926/ic.476

Korumaz, M. (2017). Talent Management in Educational Organizations. European Journal of Education Studies, 3(10), 404-424. https://doi.org/10.5281/zenodo.1019297

Kirk dan Miller dalam Moeleong, Lexy J. 1986. Metodologi Penelitian Kualitatif. Bandung: PT. Remaja Rosda Karya

Mulyadi. (2016). Kepemimpinan Kepala Sekolah Dalam Meningkatkan Kinerja Guru. Accessed on 12 April 2019. http://jurnal.untan.ac.id/index.php/jpdpb/article/ viewfile/17816/15167. accessed on 12 April 2019.

Octavia. (2016). Gaya-kepemimpinan-kepala-sekolah-dalam-upaya-meningkatkan-kinerjaguru-dan-tenaga-kependidikan. https://journal.unesa.ac.id/index.php/jdmp/article/ view/555/405. Educational Management Dynamic Journal. Accessed 12 April 2019.

Örgütsel, E., \& Rolü, G. (2018). The Role of Organizational Trust in the Effect of Leadership of School Administrators on Job Satisfaction of Teachers 1 Okul Yöneticilerinin Liderliğinin Öğretmenlerin İş Doyumuna English Version Introduction. Kuram ve Uygulamada Ĕ̈itim Yönetimi 2018,24(3), 437-482.

Raman, A., Mey, C. H., Don, Y., Daud, Y., \& Khalid, R. (2015). Relationship between principal's transformational leadership style and secondary school teachers commitment. Asian Social Science, 11(15), 221-228.

S. Uko, E. (2015). Principalship and Effective Management of Facilities in. International Journal of Academic Research and Reflection, 3(1), 64-76.

Science, C., Faculty, I. S., Science, C., Faculty, I. S., Science, C., \& Faculty, I. S. (2018). Organizing Educational Institutions Networking Cooperation Through Distance Learning Technologies. Turkish Online Journal of Distance Education-TOJDE, 19, 86-100. 
Syaefudin Saud, Udin. (2018). Theory and Practices, Educational Administration. Bandung: Alfabeta.

Tsai, Y. (2011). Relationship between organizational culture, leadership behavior and job satisfaction. BMC Health Services Research, 11(1), 98. https://doi.org/10.1186/14726963-11-98

Yahchouchi, G. (2009). Employees' perceptions of Lebanese managers' leadership styles and organizational commitment. International Journal of Leadership Studies, 4(2), $127-140$. 